\title{
The impact of relative sea level rise on the Northern Adriatic Sea coast, Italy
}

\author{
L. Carbognin ${ }^{1}$, P. Teatini ${ }^{2,1} \&$ L. Tosi ${ }^{1}$ \\ ${ }^{1}$ Institute of Marine Sciences, National Research Council, Venice, Italy \\ ${ }^{2}$ Department of Mathematical Methods and Models or Scientific \\ Applications, University of Padua, Italy
}

\begin{abstract}
The lowlying coast of the Northern Adriatic Sea, between the Venetian territory to the north and the Ravenna area to the south, is very sensitive to land and sea elevation changes. Subsidence assessments show that geological land subsidence has and continues to occur unevenly at different rates (from less than 1 to more than $5 \mathrm{~mm} / \mathrm{yr}$ ), ascribable primarily to sediment compaction and secondly to deformation of substratum. Anthropogenic subsidence, mainly due to groundfluid removal, has severely occurred in the second half of 1900 reaching values of some centimetres in the Venice area and a few meters southward. Starting in the 1970s, however, with the halt of groundwater withdrawals, anthropogenic subsidence has been strongly reduced or stopped. The availability of tide gauge data in Trieste, Venice, and Ravenna, along the Northern Adriatic coast, allows accurate assessment and meaningful observations of sea level changes. The analysis of data recorded from 1890 to 2007 shows negative trends of relative sea level equal to $1.2 \mathrm{~mm} / \mathrm{yr}$ in Trieste, $2.5 \mathrm{~mm} /$ year in Venice, and $8.5 \mathrm{~mm} / \mathrm{yr}$ in Ravenna. Since Trieste is known to be stable, the rate of $1.2 \mathrm{~mm} / \mathrm{yr}$ is attributable to the eustatic rise only. The comparison between Trieste and the other two cities shows that the trend at Venice and Ravenna is significantly influenced by land subsidence that is responsible for about the $57 \%$ and $85 \%$, respectively, of the recorded relative sea/ground elevation changes. The relative sea level rise has induced modifications in geomorphologic and ecological features of the entire coast.
\end{abstract}

Keywords: Northern Adriatic coast, geomorphologic features, sea level rise, land subsidence, environmental impact, flooding. 


\section{Introduction}

The Northern Adriatic coastal area, from the Venice region northward to the Ravenna region southward (fig. 1), is underlain by a subsiding sedimentary basin.

Changes in ground elevation with respect to the Adriatic sea level have caused very deep modifications in its physiographical features over the last millennia, during the post Würmian climate improvement from about 12,000 to 6,000 yrs BP. The Venice Lagoon originated at the end of this phase [1], the formation of the deltaic system of Po River dates back 2,000 yr ago [2] and the Ravenna coast reached the present location only a couple of centuries ago [3]. Changes in coastal morphology and hydrodynamics have been controlled by the relative sea level rise, i.e. the interaction between land subsidence and eustasy. Anthropogenic processes and interventions have primary modified the coastline evolution over the XX century. The coast of the Northern Adriatic Sea is the Italian area at greatest risk where peculiar vulnerable low-lying systems such as deltas, islands, wetlands, plains, and coastal cities are found. The availability of

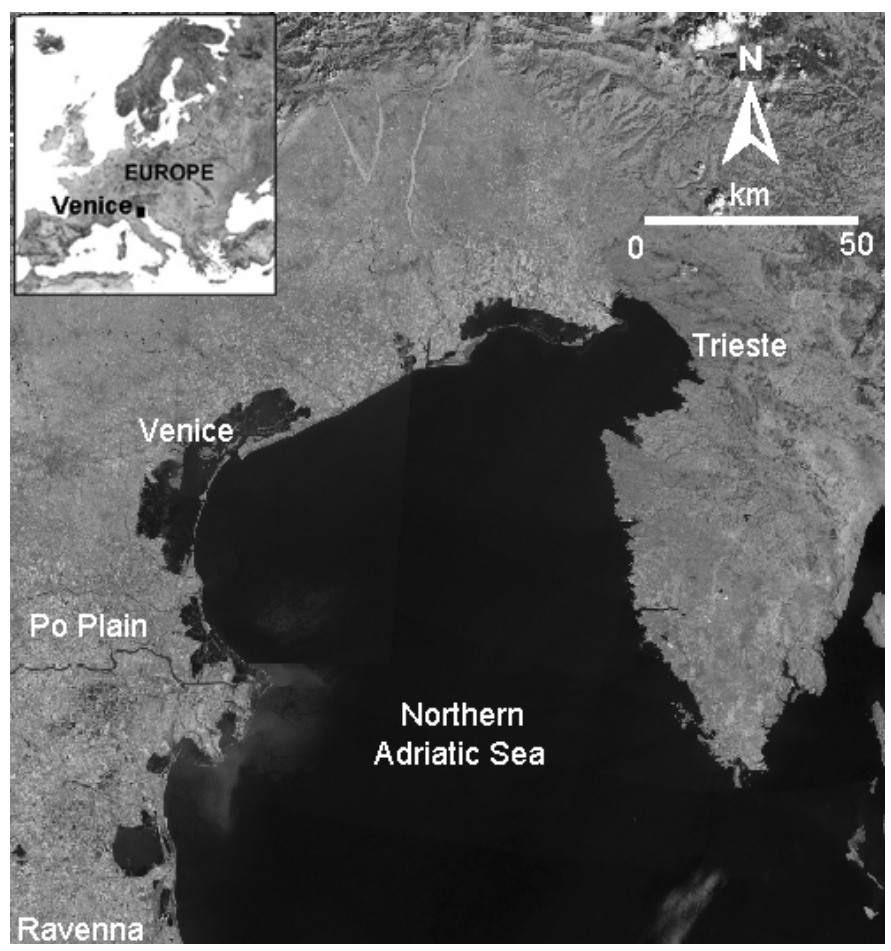

Figure 1: Satellite image of the Northern Adriatic Sea and coastland with the location of the cities of Trieste, Venice and Ravenna cities. 
secular surveys on land motion and tide gauge data for Trieste, Venice, and Ravenna allow accurate assessment of relative sea level trend in the Northern Adriatic Sea.

\section{Relative sea level rise}

The low coast of the Northern Adriatic Sea is very sensitive to land and sea elevation changes. Subsidence and eustacy have been the most important processes inducing morphological changes; over the last half a century the entire coast has experienced a serious relative sea level rise, the main component of which is land subsidence.

\subsection{Land subsidence}

\subsubsection{Venice region}

Vertical displacements in the Northern Adriatic coastal areas are caused by both natural and anthropogenic factors, acting individually or together and on different timescales (millions to thousands and hundred to tens of years), thus reflecting the geological history and the human development of the territory.

The role played by the long-term natural causes, i.e. tectonics and glacioisostasy, is negligible in modern times, while natural compaction of recent alluvial fine-grained deposits, that increase from the mainland toward the sea, has assumed a major importance. As a general statement a close correlation exists between the thickness of the Neozoic formations and the amount of natural subsidence, so that the sinking rate exhibits a non-uniform space distribution [4]. Subsidence assessments show that natural land subsidence has and continues to occur unevenly at different rates. In particular it has been estimated in the range of $0.5-1.0 \mathrm{~mm} / \mathrm{yr}$ in the Venetian territory [5,6], about $2.0-2.5 \mathrm{~mm} / \mathrm{yr}$ in the Ravenna area [7], and twice as much in the Po River delta [8].

Anthropogenic subsidence due to subsurface fluid pumping become a key problem for the land stability over the XX century, and especially after World War II, when the civil, industrial, agricultural, and tourist development required huge amounts of water and an increasing energy supply. The only difference is the nature of the fluid withdrawn: artesian water in the Venice area, gas-bearing water in the Po Delta, and both groundwater and, more locally, gas from deep inshore and offshore reservoirs in the Ravenna region [8]. From the early 1970s, countermeasures have been taken and anthropogenic subsidence strongly reduced or stopped all over the eastern Po plain. The cumulative subsidence has reached values of some centimetres in the Venice area, 2-3 m in the Po River delta, and as much as $1.5 \mathrm{~m}$ southward along the Romagna coastland with serious environmental impacts.

In particular, all over the Venetian district the most critical rates of about $17 \mathrm{~mm}$ in the Marghera industrial zone and $14 \mathrm{~mm}$ in Venice were measured between 1968 and 1969. Between 1952 and 1969 the average land sinking totalized about $11 \mathrm{~cm}$ in the industrial zone and $9 \mathrm{~cm}$ in the historical centre [9]. Although generally negligible in inland areas, these values have been highly 
significant for the lagoon and the city of Venice. The regional surveys carried out in 1993 and in 2000 have been of particular significance. They confirmed the stability of the mainland, Venice, and the central part of the lagoon, and shown subsidence rates up to $5 \mathrm{~mm} / \mathrm{yr}$ along the littoral and at the northern and southern extremities of the lagoon edge [10].

Now geomechanical subsidence is generally under control, but because the sinking phenomenon is mostly irreversible, many of the induced effects still remain. Recently, ad hoc researches have shown that some portions of farmland bounding the lagoon are subsiding due to the biochemical oxidation of the soil organic matter. Also the widespread seawater intrusion along the coastal margin appears a further cause of "geochemical" subsidence caused by the salinization of the interstitial water in clay layers [11].

By the innovative "Subsidence Integrated Monitoring System" (SIMS), which efficiently merges the different displacement measurements obtained by levelling, differential and continuous Global Positing System (GPS), and Synthetic Aperture Radar (SAR)-based interferometry, a high resolution map of the present land subsidence of the entire Venice coastal region have been obtained (fig. 2). The map, which refers to the 1992-2002 decade and covers an

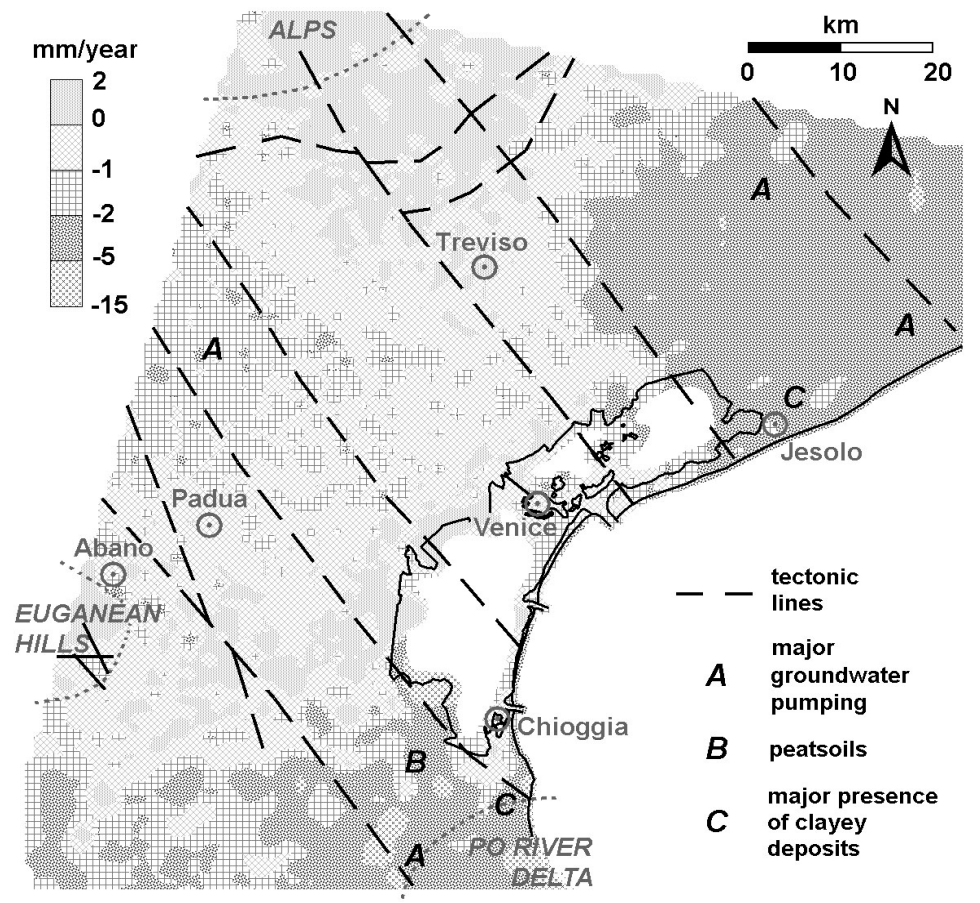

Figure 2: Map of the displacement rates (mm/year) in the Venice region obtained by the SIMS over the decade 1992-2002. The major factors that are responsible for the observed movement are shown (after [12]). 
area of about $100 \times 100 \mathrm{~km}^{2}$, has pointed out a significant spatial variability of the ground vertical movements, both at regional and local scales, and displacement rates ranging from a slight $(1-2 \mathrm{~mm} / \mathrm{yr})$ uplift to a serious subsidence of more than $10 \mathrm{~mm} / \mathrm{yr}$ [12].

\subsubsection{Po River delta}

Considering both the magnitude and the seriousness of the environmental impact, the Po River delta is the most severe case of induced land subsidence in Italy. The compaction caused by rash exploitation of the gas-bearing water largely prevailed on natural subsidence rate estimated about $5 \mathrm{~mm} / \mathrm{yr}$. Extraction of methane from the five Quaternary aquifers located between $100 \mathrm{~m}$ and $600 \mathrm{~m}$ depth was performed from 1938 and mainly over the period 1950-1964. A sinking rate up to $30 \mathrm{~cm} / \mathrm{yr}$ was measured between 1950 and 1957 in the heart of the delta where the main pumping centres were located [13]. A cumulative subsidence ranging from about $50 \mathrm{~cm}$ to $3 \mathrm{~m}$ finally occurred (fig. 3).

The rates recorded by a levelling survey in 2000 are decidedly reassuring although they are in general still higher than those ascribable to the natural subsidence [14].
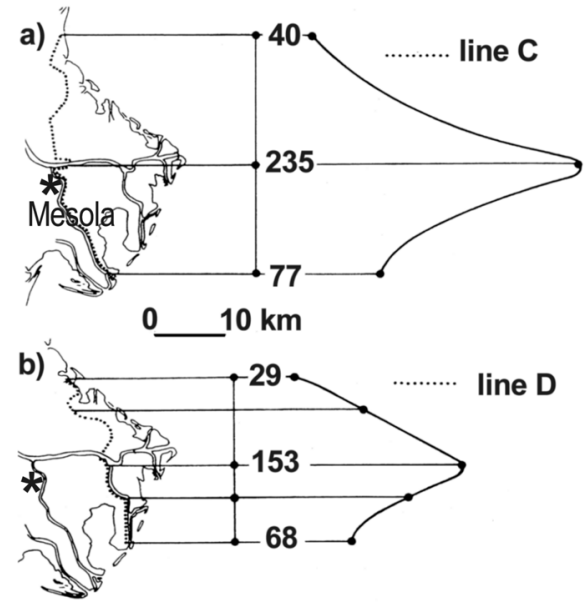

Figure 3: Subsidence (cm) in the Po River Delta area from 1950 to 1970 along two lines: line $\mathrm{C}$ spanning the central area, line $\mathrm{D}$ running more close to the external belt (after [15]).

\subsubsection{Ravenna coastland}

Geodetic surveys carried out from 1953 to 2003 along the Ravenna coast area provide evidence of a cumulative land settlement exceeding $1 \mathrm{~m}$ at some portions of the coastland (fig. 4). The largest settlement rate of $110 \mathrm{~mm} / \mathrm{yr}$ was recorded at the Ravenna coastland between 1972 and 1973 [16].

A close relationship has been verified between land settlement and groundwater withdrawal and, locally, gas exploitation. Although surveys performed over the last decade show a substantial inland stability, nevertheless 
142 Management of Natural Resources, Sustainable Development and Ecological Hazards II

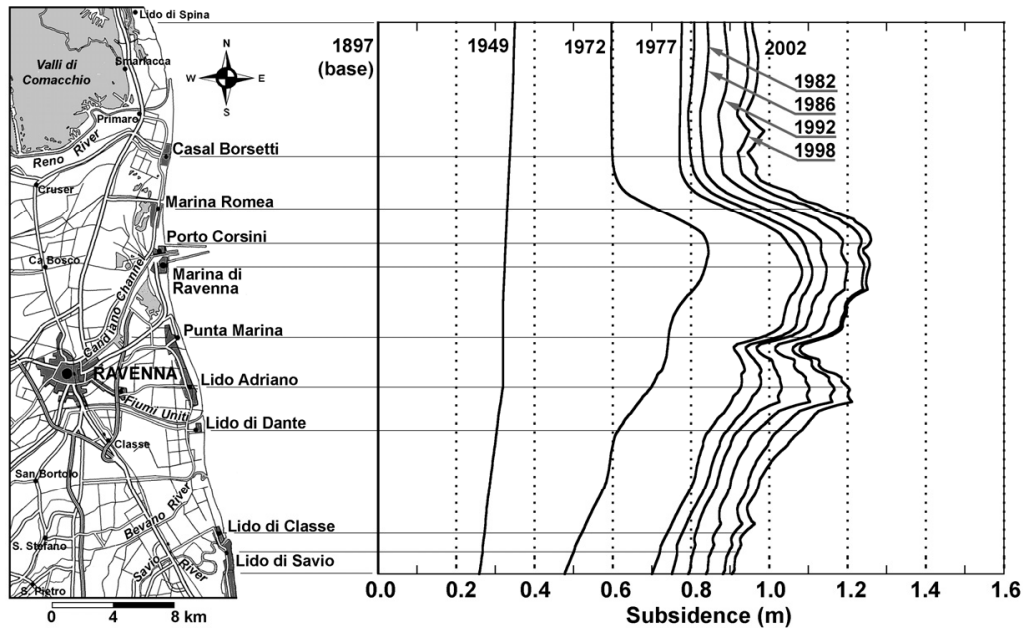

Figure 4: Land subsidence versus time along the shoreline of the Ravenna Municipality obtained from levelling data (after [7]).

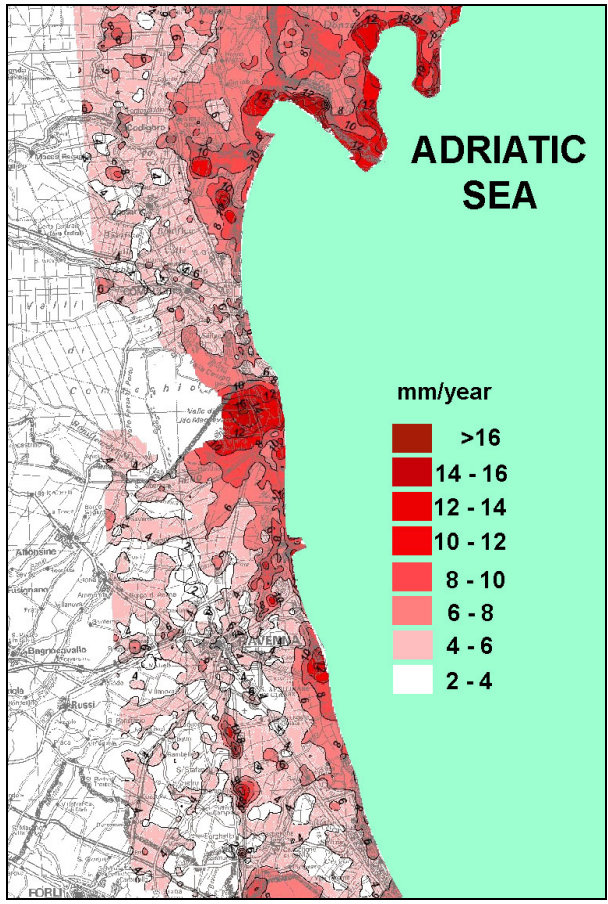

Figure 5: Land subsidence rate in the Romagna coastland from InSAR over the 1992-2000 period (after [18]).

subsidence still continues over a few kilometre wide coastal strip at a rate of about $10 \mathrm{~mm} / \mathrm{yr}$ (fig. 5), i.e., significantly larger than the natural one [7, 16, 17]. 


\subsection{Eustacy}

Increase of the sea level during the XX century and at present is a well documented process worldwide that is linked to climate changes, mainly ice melting and the consequent variation in the mass and volume of oceans. The relatively modest warming recorded thorough the last century has however induced rises of sea level around the world that have approached $12-20 \mathrm{~cm}$. In this respect, it is important to point out that long tide-gauge records around the world show that the eustatic rate in the Northern Adriatic Sea, along with the whole Mediterranean Sea, is consistently lower (approximately 35\%) than the global mean value [19]. This was attributed to NAO induced changes in atmospheric pressure, temperatures, and salinity variation, on account also of the specific features of this almost closed sea [20].

An analysis of the mean sea level registrations at the coastal stations of Trieste, Venice, and Ravenna (fig. 1) over the period from 1890 to 2007 show results that vary considerably between the different areas (fig. 6). Although presenting short-cycle fluctuations, the historical tide-gauge data for Trieste are characterized by a unique linear trend for the whole period, with a mean eustatic rise of $0.12 \mathrm{~cm} / \mathrm{yr}$.

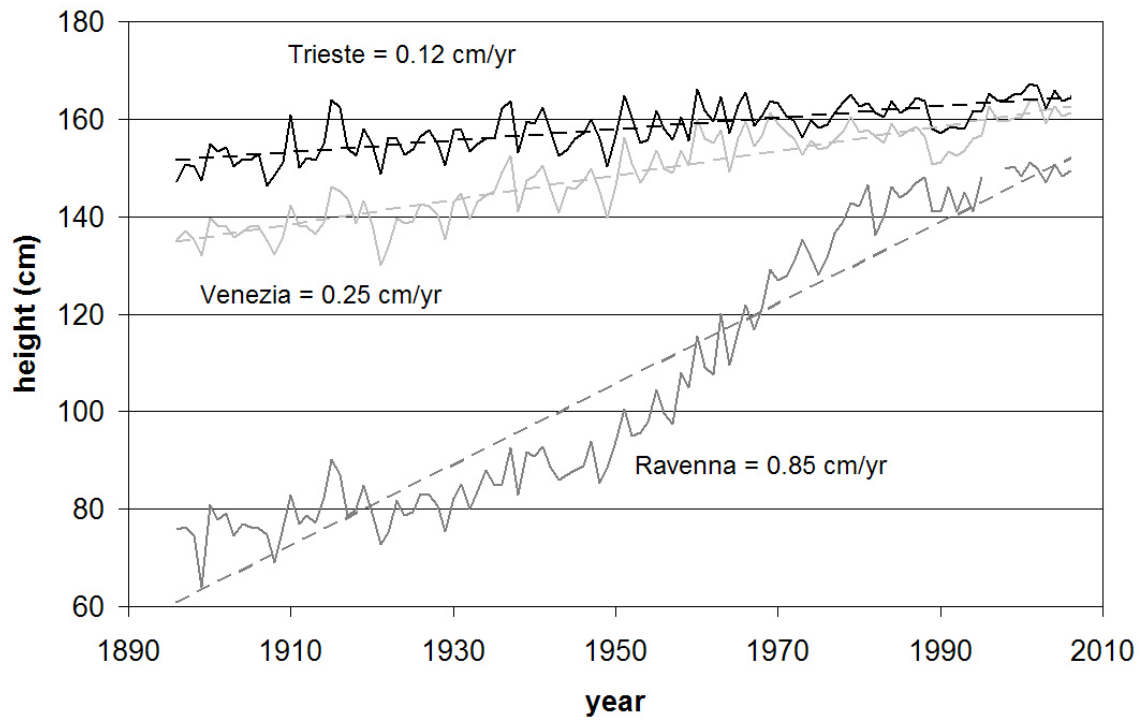

Figure 6: Mean sea levels at Trieste, Venice, and Ravenna from 1890 to 2007. The linear regressions of the yearly values are represented together with the average eustatic rate. Ravenna records have been updated after [21]. Venice and Trieste records after [22].

On the other hand, the average rising rate for the mean sea level at Venice and Ravenna is equal to $0.25 \mathrm{~cm} / \mathrm{yr}$ and $0.85 \mathrm{~cm} / \mathrm{yr}$, respectively. Even much higher occurred in the period between the 1950s and the 70 s due to the temporary influence of anthropogenic subsidence. 
Since Trieste is located on a stable area, the rate of $0.12 \mathrm{~cm} / \mathrm{yr}$ is attributable to the eustatic rise only [22]. This value is in good agreement with the eustatic rise measured at other stations in the Mediterranean Sea [20]. Considering the shape of the Adriatic Sea and the relative location of the tide gauges, it is plausible to assume as true the trend in Trieste, and apparent those computed in Venice and Ravenna where the influence of land subsidence on the relative sea/ground elevation changes results equal to $57 \%$ and $85 \%$, respectively (fig. 7).
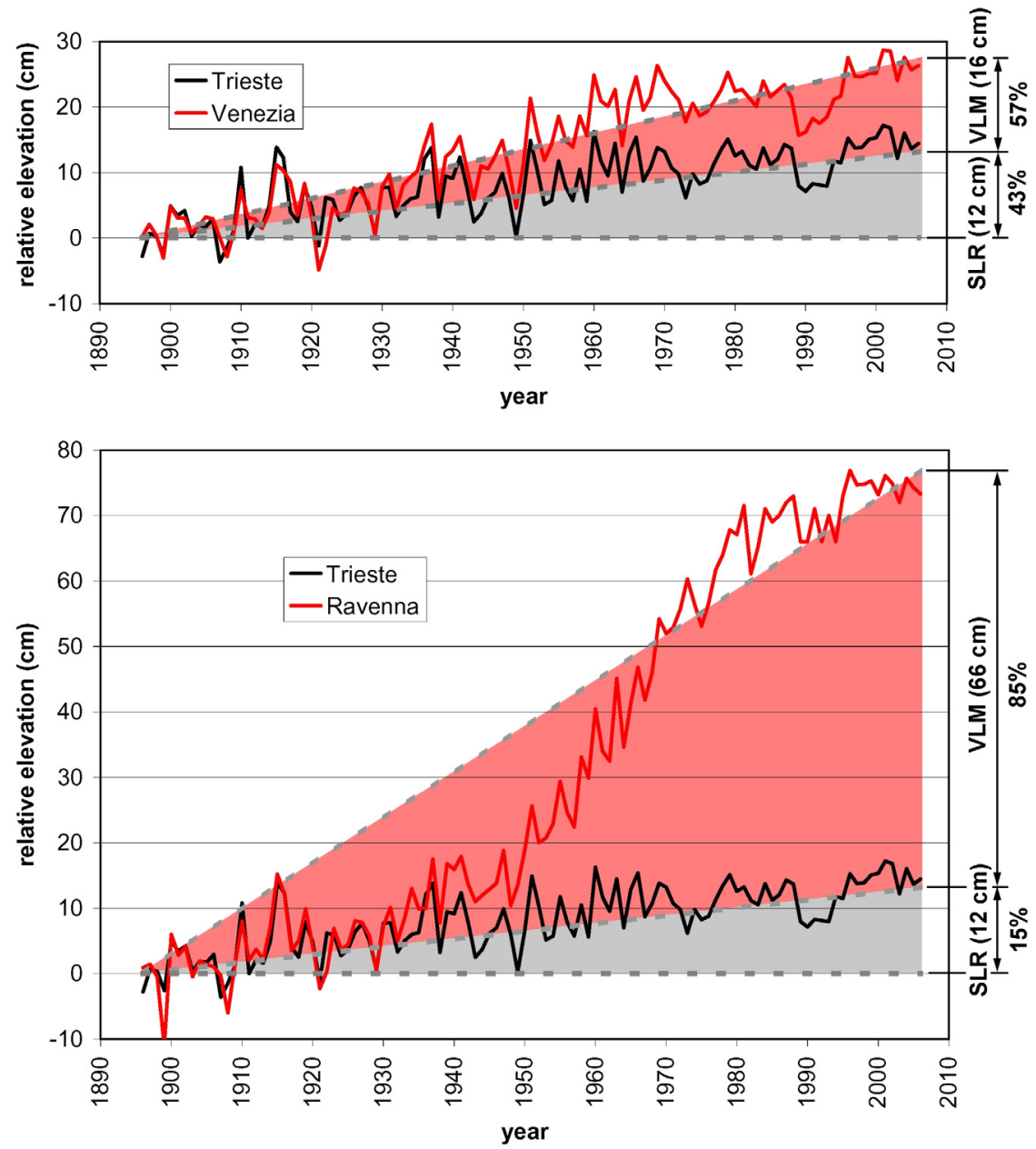

Figure 7: Yearly average sea levels from tide gauges of Venice and Ravenna compared with that of Trieste over the period between 1896 and 2007. At Venice and Ravenna the contribution of land subsidence (VLM) to the overall relative sea level rise is separated from the contribution due to the eustatic sea level rise (SLR) using the tide gauge records at Trieste. 
Unfortunately, no long tide gauge series are available at the Po River delta. Nevertheless on the basis of the considerations presented just above and the subsidence occurred in this area, it is possible to extrapolate that the influence of land sinking on the relative sea/ground elevation change has been 2-3 times greater than that computed for the Ravenna coast.

\section{Discussion and concluding remarks}

Relative sea level rise currently appears to be the main parameter for the increased vulnerability of coastal areas in the Northern Adriatic basin. The combined effect of land subsidence and sea level rise has threatened the industrial areas, the urban zones, and the surrounding vast marshland reclamations which become more prone to being submerged. A variation in the relationship between the land and the sea has occurred along the entire coast, with notable changes in geomorphological and ecological features [23]. The impacts of relative sea level rise include erosion, striking coastline regression concurrently with the deepening of the bottom slope near the shoreline, coastal inundations, and the destruction of the pine forest in some places along the Ravenna coastline [16].

Due to the serious amount of the occurred relative sea level rise, a noteworthy saltwater intrusion in shallow aquifers and surficial waters has occurred along the Northern Adriatic coast as documented by [24, 25]. In the Po River Delta the morpho-ecological setting of the territory was completely altered and in its more internal zones, changes occurred in the hydrographic net with the inversion of the original discharge direction. Some areas become brackish swamps with severe consequences on the ecological system. Soil contamination by saltwater (fig. 8) has had detrimental consequences on the agricultural and fishing activities of the region, which are normally located in transitional zones (i.e. the Goro/Gorino lagoon-marshy areas). The increase of

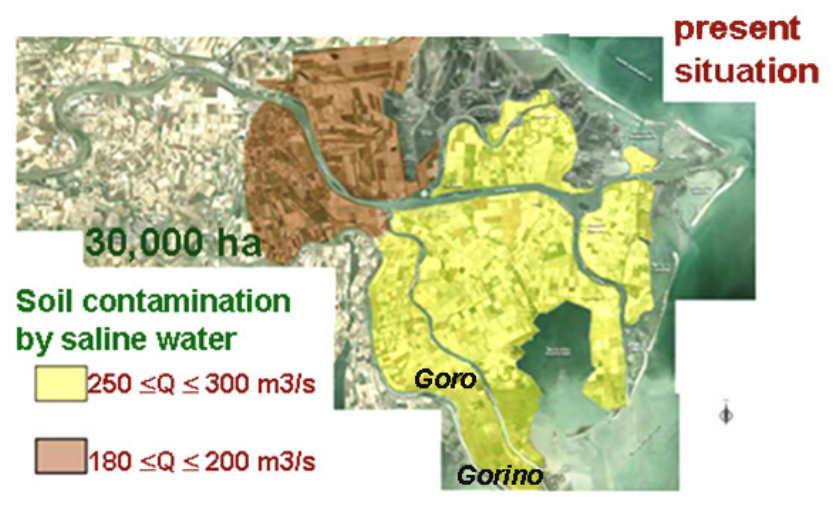

Figure 8: Extent of the areas where saline water has definitely contaminated the soil in the Po River delta (modified after [25]). Q is the Po River discharge. 
sea intrusion inshore along the watercourses has worsened the compaction of clayey sediments enhancing the subsidence process.

In the Venetian area, the relative sea level has risen by about $25 \mathrm{~cm}$ from the beginning of 1900 until today [10]. This apparently modest figure has become of crucial importance for Venice, with its singular relationship with the water within a complex lagoon basin. These $25 \mathrm{~cm}$ represents the main threat for the survival of the historical city, emerging today only $90 \mathrm{~cm}$ above the Northern Adriatic. Presently, relative sea level rise has increased the flood frequency by more than seven times with severe damages to the urban heritage, enhances erosion processes within the lagoon, and worsened the precariousness of the coastal strip, thus requiring ever more frequent restorative interventions [26].

One can say that the entire Northern Adriatic low coast is already experiencing the effects of the expected variation in climatic conditions, associated with the risk of a global rise in sea level. Even if land subsidence is no longer a major threat, further few centimetres of rising sea could be a serious peril for the survival of these coastal zones. Keeping in mind the imperative duty "Venice must be saved" the Italian Government decided for the construction of mobile barriers at the three lagoon inlets, the so-called Mo.S.E., i.e. Modulo Sperimentale Elettromeccanico, (experimental electromechanical module) project [27], to prevent water exchange with the lagoon any time the elevation in the Adriatic sea achieves the $110 \mathrm{~cm}$ height above datum.

During the twenty first century, sea level is expected to rise considerably faster that in the twentieth [28], but because of uncertainties in the climate forecasting, it is not clear how rapidly this will occur. In particular, uncontroversial projections for the Adriatic Sea, that assumes very peculiar and different characteristics due to its shape and low depth, are still not available. On this base it has seemed plausible to propose local perspectives of relative rising sea level over the next century at Venice considering the regional history of the sea level trend, along with the IPCC A1B mid-range [22]. At the date, the results show that the projections of relative sea level by 2100 give a large range of possible conditions from 17 to $53 \mathrm{~cm}$, i.e. between a moderate nuisance to an unsustainable aggression. In fact the flooding events of $110 \mathrm{~cm}$ above the local datum or more could increase to 20-250 times per year with respect to the present annual frequency of 4 times Although this rise will not happen suddenly, and more precise forecasts will be performed in the future, complementary solutions suitable to completely protect Venice from flooding should be investigated and an ad hoc management and planning of the defence of the city must be performed in advance.

\section{References}

[1] Gatto, P. \& Carbognin, L., The Lagoon of Venice: Natural environmental trend and man-induced modification. Hydrological Sciences Bulletin, 26/4/12, pp. 379-391, 1981.

[2] Stefani, M. \& Vincenzi, S., The interplay of eustacy, climate and human activity in the late Quaternary depositional evolution and sedimentary 
architecture of the Po Delta system. Marine Geology, 222-223, pp. 18-48, 2005.

[3] Elmi, C., Colantoni, P., Gabbianelli, G. \& Nesci, O., Holocene shorelines along the central Adriatic coast (Italy) Geo. Acta 1, pp. 27-36, 2001.

[4] Tosi, L., Teatini, P., Carbognin, L. \& Brancolini, G., Using high resolution data to reveal depth-dependent mechanisms that drive land subsidence: The Venice coast, Italy. Tectonophysic, doi: 10.1016/j.tecto.2009.02.026, 2009.

[5] Bortolami, G., Carbognin, L. \& Gatto, P., The natural subsidence in the Lagoon of Venice, Italy. Land Subsidence, IAHS Publ. no. 151, pp. 777$785,1985$.

[6] Kent, V.D., Rio, D., Massari, F., Kukla, G. \& Lanci, L., Emergence of Venice during the Pleistocene. Quaternary Science Rev., 21, pp. 17191727, 2002.

[7] Teatini, P., Ferronato, M., Gambolati, G., Bertoni, W. \& Gonella, M., A century of land subsidence in Ravenna, Italy. Environmental Geology, 47(6), pp. 831-846, 2005.

[8] Colantoni, P., Galligani, P. \& Lenaz R., Late Pleistocene and Holocene evolution of the North Adriatic continental shelf (Italy). Marine Geology, 33, pp. M41-M50, 1979.

[9] Carbognin, L., Gatto, P., Mozzi, G. \& Gambolati, G., Case History N. 9.3. Venice, Italy. Guidebook on Land Subsidence due to Groundwater Withdrawal, Eds. J. Poland et al., Unesco Printer, Paris (France), pp. 161-174, 1984.

[10] Carbognin, L., Teatini, P. \& Tosi, L., Relative land subsidence in the lagoon of Venice. J. Marine Systems, 51(1-4), pp. 345-353, 2004.

[11] Carbognin, L., Gambolati, G., Putti, M., Rizzetto, F., Teatini, P.\& Tosi, L., Soil contamination and land subsidence raise concern in the Venice watershed, Italy. Management of Natural Resources, Sustainable Development and Ecological Hazards, Eds. C.A. Brebbia et al., WIT Press., pp. 691-700, 2006.

[12] Teatini, P., Tosi, L., Strozzi, T., Carbognin, L., Wegmüller, U. \& Rizzetto, F., Mapping regional land displacements in the Venice coastland by an integrated monitoring system. Remote Sens. Environ., 98, pp. 403-413, 2006.

[13] Caputo, M., Pieri, L. \& Unguendoli, M., Geometric investigation of the subsidence in the Po Delta. Bollettino di Geofisica Teorica e Applicata, 47, pp. 187-207, 1970.

[14] Carbognin L., Frankenfield Zanin, J. \& Marabini, F., River Delta Region, Italy. An overview of Environmental Evolution and Land Subsidence. (C) CNR, Venice, Italy, printed by "La Garagola", 42 pp., 2000.

[15] Carbognin, L., Gatto, P. \& Marabini, F., Correlation between shoreline variations and subsidence in the Po River Delta, Italy. Land Subsidence, Eds. A.I. Johnson et al., IAHS n. 151, pp. 367-372, 1984. 
[16] Carbognin, L., Gatto, P. \& Mozzi, G., Case history no.9.15: Ravenna, Italy. Guidebook on Land Subsidence due to Groundwater Withdrawal, Eds. J. Poland et al., Unesco Printer, Paris (France), pp. 291-305, 1984.

[17] Teatini, P., Ferronato, M., Gambolati, G. \& Gonella, M., Groundwater pumping and land subsidence in the Emilia-Romagna coastland, Italy: Modeling the past occurrence and the future trend. Water Resources Research, 42, W01406, doi:10.1029/2005WR004242, 2006.

[18] Bonsignore, F., Land subsidence monitoring in Emilia-Romagna. In: Water, soil, climate: knowing to manage. I Quaderni di Arpa, Arpa Emilia-Romagna, pp 13-20, 2003.

[19] Holgate, S. J., On the decadal rates of sea level change during the twentieth century. Geophys. Res. Lett., 34, L01602, doi:10.1029/2006GL028492, 2007.

[20] Tsimplis, M. N. \& Rixen, M., Sea level in the Mediterranean Sea: The contribution of temperature and salinity changes. Geophys. Res. Lett., 29, 2136, doi:10.1029/2002GL015870, 2002.

[21] Regione Emilia-Romagna- IDROSER SpA, Progetto di piano per la difesa dal mare e la riqualificazione ambientale del litorale della Regione Emilia-Romagna. Relazione generale, by Mentino Preti, Ed. IDROSER SpA Bologna, 365 pp., 1996.

[22] Carbognin, L., Teatini, P., Tomasin, A. \& Tosi, L., Global change and relative sea level rise at Venice: What impact in term of flooding. Climate Dynamics, doi: 10.1007/ s00382 -009-0617-5, 2009.

[23] Carbognin, L. \& Tosi, L., Interaction between climate changes, eustacy and land subsidence in the North Adriatic region, Italy. Marine Ecology, 23/1, pp. 38-50, 2002.

[24] Antonellini, M., et al., Salt water intrusion in the coastal aquifer of the southern Po Plain, Italy, Hydrogeology Journal, 16(8), pp. 1541-1556, 2008 .

[25] Luchetta, A., Il Delta del Po: Ecosistema Sensibile tra Uomo e Natura. National Conference on Climate Changes, Roma, 12-14 Sept. 2007, http:/www.conferenzacambiamenticlimatici2007.it, 2007.

[26] Carbognin, L., Cecconi, G. \& Ardone, V., Interventions to safeguard the environment of the Venice Lagoon (Italy) against the effects of land elevation loss. Land Subsidence, Eds. L. Carbognin et al., La Garangola Publ. (Italy), Vol. I, pp. 309-324, 2000.

[27] Gentilomo, M. \& Cecconi, G., Flood protection system designed for Venice. Hydropower Dams, 2, pp. 46-52, 1997.

[28] IPCC - Intergovernmental Panel on Climate Change, Climate Change 2007: Synthesis Report, Geneva, 52 pp., 2007. 